\title{
Adaptation of a container tank to a savonius vertical axis turbine analyzed by reverse engineering
}

\section{Adaptación de tanque contenedor a una turbina de eje vertical savonius analizada por ingeniería inversa}

MORALES-PALOMARES, David*†, CRUZ-GÓMEZ, Marco Antonio, JUAREZ-ZERÓN, Tomás Aarón and FLOREZ-MARTINEZ, Guillermo

Benemérita Universidad Autónoma de Puebla; Facultad de Ingeniería, Grupo de Tribología y Transporte, Cuerpo Académico 189 (Prevención de Desastres y Desarrollo Sustentable, Tribología, BUAP), Edificio de Posgrado, Primer Nivel, Cubículo No. 16, Blvd. Valsequillo esq. Av. San Claudio, Ciudad Universitaria, Col. San Manuel, CP. 72570, Puebla México.

ID $1^{\text {st }}$ Author: David, Morales-Palomares / ORC ID: 0000-0001-5637-2258, Researcher ID Thomson: AAM-5888-2021, CVU CONACYT ID: 1129650

ID $1^{\text {st }}$ Co-author: Marco Antonio, Cruz-Gómez / ORC ID: 0000-0003-1091-8133, Researcher ID Thomson: S-3098-2018, CVU CONACYT ID: 349626

ID $2^{\text {nd }}$ Co-author: Tomás Aáron, Juárez-Zerón / ORC ID: 0000-0002-9796-0540, Researcher ID Thomson: S-3099-2018, CVU CONACYT ID: 295058

ID $3^{\text {rd }}$ Coauthor: Guillermo, Flores-Martinez / ORC ID: 0000-0002-2243-2379, Researcher ID Thomson: G-3384-2019, CVU CONACYT ID: 169853

DOI: $10.35429 / J T I P .2021 .13 .5 .1 .7$

Received July 30, 2021; Accepted October 30, 2021

\begin{abstract}
Due to the alarming climatic situation experienced by all nations, we are in the need to urgently develop and improve sustainable technologies for power generation in order to supply the growing demand for power generation in power systems worldwide. This project aims to design and build a prototype vertical axis wind turbine Savonius analyzed by reverse engineering process by adapting the structure of a tank and taking advantage of its shape and dimensions, with the intention of building a wind turbine with the lowest possible budget, In addition, data from the psychrometric chart of the state of Puebla (winter-spring) will be used so that by means of numerical simulations of fluid flow using CFD software we can obtain the parameters of linear velocity, angular velocity, drag coefficient and projected power that the wind rotor will be able to develop.
\end{abstract}

Savonius, Wind Energy, CFD

\begin{abstract}
Resumen
Debido a la alarmante situación climática que experimentan todas las naciones, nos vemos en la necesidad de desarrollar y mejorar con urgencia las tecnologías sustentables para la generación de energía eléctrica con el fin de abastecer la creciente demanda de generación en los sistemas eléctricos de potencia a nivel mundial. Este proyecto tiene como objetivo diseñar y construir un prototipo de aerogenerador de eje vertical Savonius analizado mediante el proceso de ingeniería inversa adaptando la estructura de un tanque y aprovechando su forma y dimensiones, con la intención de construir un aerogenerador con el menor presupuesto posible, además se utilizarán los datos de la carta psicrométrica del estado de Puebla (invierno-primavera) con el fin de que por medio de simulaciones numéricas de flujo de fluidos utilizando un software CFD logremos obtener los parámetros de velocidad lineal, velocidad angular, coeficiente de arrastre y potencia proyectada que sea capaz de desarrollar el rotor eólico.
\end{abstract}

Savonius, Energía eólica, CFD

Citation: MORALES-PALOMARES, David, CRUZ-GÓMEZ, Marco Antonio, JUAREZ-ZERÓN, Tomás Aarón and FLOREZ-MARTINEZ, Guillermo. Adaptation of a container tank to a savonius vertical axis turbine analyzed by reverse engineering. Journal of Technologies in Industrial Processes. 2021. 5-13: 1-7

\footnotetext{
* Author Correspondence (david.moralespa@ correobuap.mx)

$\dagger$ Researcher contributing as first author.
} 


\section{Introduction}

Due to the alarming climate situation that all nations are experiencing, we urgently need to study, develop and improve sustainable technologies for electric generation to meet the growing demand for power generation in the world's electric power systems. The main reason why it is of interest to study vertical axis turbines is the fact that they do not need to be guided in the direction of the wind flow, these models handle turbulence better than horizontal axis turbines, therefore, vertical axis turbines are excellent to be implemented in an urban scenario developing their full potential. Institulo tecnológico y de Estúdios Superiores de Monterey. (2020).

The objective of this research is to generate a Savonius vertical axis turbine by adapting a tank, taking advantage of its shape and dimensions. From the turbine generated by the reverse engineering process, we sought to obtain the operating parameters of this wind rotor. We seek to provide data on angular velocity, intercepted force, and projected power of Savonius designs which are similar to the one built.

We transferred the geometry of the Savonius wind rotor to a CAD program, and from this model, boundary conditions of the state of Puebla were declared by consulting the psychometric chart and using the measurements obtained by an anemometer. The results obtained are the product of a CFD numerical simulation, declaring a constant wind flow of $8.03 \mathrm{~m} / \mathrm{s}$ in a direction perpendicular to the axis of the Savonius turbine; in addition, control volume was imposed according to the dimensions of the wind rotor. Benemérita Universidad Autónoma de Puebla [BUAP]. (2020) y Takeshi I. et al. (2020).

Due to the turbine radius of $0.4425 \mathrm{~m}$, we expect to obtain an angular velocity of 18.1468 $\mathrm{rad} / \mathrm{s}$, estimating a unit drag coefficient.

\section{Methodology}

This research was done under a mixed methodology using both quantitative and qualitative approaches. For the quantitative approach, we used data from the psychrometric chart of the state of Puebla, measurements with an anemometer, and the design dimensions of a $200 \mathrm{~L}$ tank.
The quantitative data obtained will be declared in CFD software in order to synthesize and process the information, and thus provide a reference point in future designs of Savonius vertical axis turbines, in addition to recognizing their generation potential. The objective is to build a Savonius vertical axis turbine from the adaptation of a container tank and low-cost elements, capable of operating under the geophysical conditions of the state of Puebla. It was decided to adapt a barrel tank due to its potential to modify the strategic positions of its parts and its geometric characteristics.

The study was conducted with an average linear wind speed of $8.03 \mathrm{~m} / \mathrm{s}$ during the winterspring period. From these data, the turbine was modeled in a CAD program, followed by the quantitative data as boundary conditions, simulating a constant flow perpendicular to the axis of the Savonius turbine and obtaining the behavior of the wind rotor under these conditions. From the qualitative data, it was decided to perform the study declaring a constant wind flow, a control volume was declared in the CFD simulation to simplify the numerical solutions.

With these studies, the aim is to present the behavior of the wind flow and the turbine itself for common Savonius vertical axis designs..

\section{Design and materialization of vertical axis turbine Savonius}

The idea of adapting a tank to build the wind turbine was given due to the incredible potential and excellent performance offered by a standardized $200 \mathrm{~L}$ tank because with a few modifications both in the parts and in its strategic positioning we managed to make a fully functional Savonius turbine model in all conditions. Since it is an adaptation to the full extent of the word, the calculations were carried out using the reverse engineering method.

Given the dimensions of the $200 \mathrm{~L}$ barrel, it was decided to grind the upper and lower faces as well as the barrel cylinder to obtain five blades, thus obtaining a total of seven pieces, all this was modeled in the CAD tool SolidWorks 2018 free license as shown in Figure 1. 


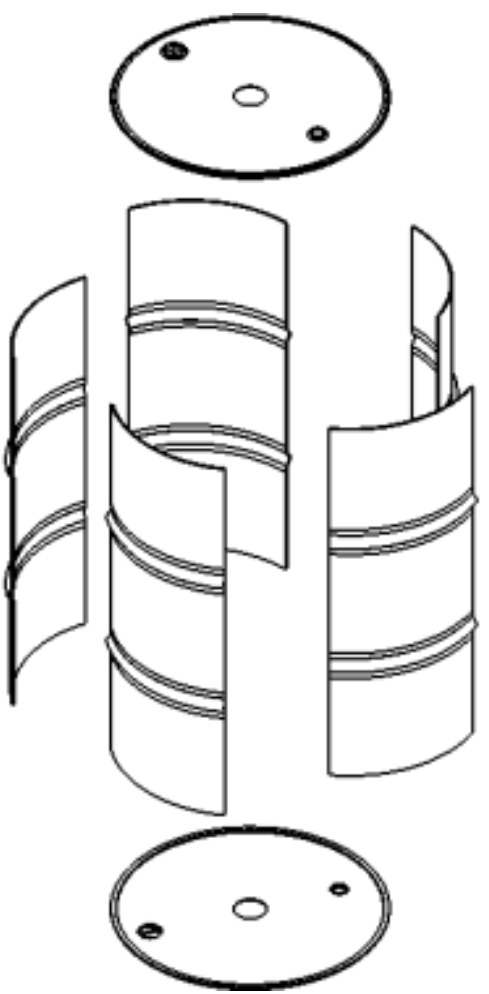

Figure 1 Parts that integrate the assembly

Source: Tribology and transport group Faculty of Engineering BUAP; Solidworks 2018. (2021)

Now, an inclination of $35^{\circ}$ was proposed for the blades by rotating them for a point located at $24^{\circ}$ from the axis to keep a portion of the blade within the circumference of the faces at the base of the assembly strategically to increase the contact area with the base and consequently the strength of the assembly as shown in figure 2 .

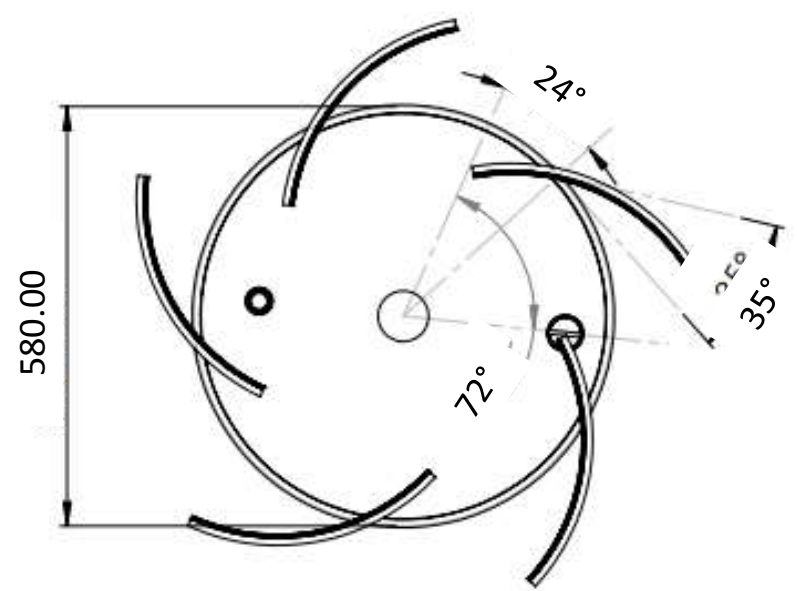

Figure 2 Positioning of the Savonius turbine blades Source: Tribology and transport group Faculty of Engineering BUAP; Solidworks 2018. (2020)

After relocating the positions of the parts we obtained the preliminary design of the Savonius turbine as shown in Figure 3. At this point, we proposed the manufacturing processes necessary to materialize the design.

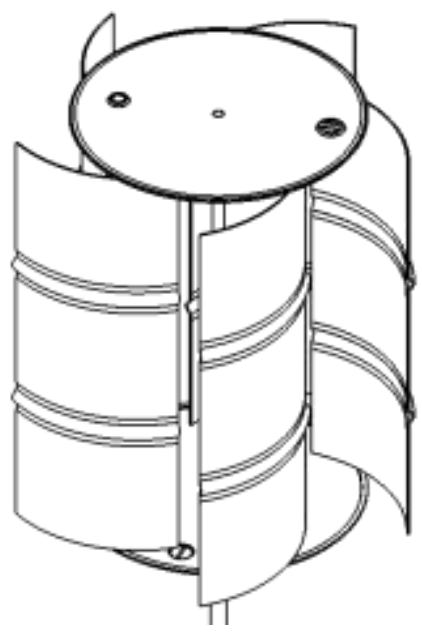

Figure 3 Preliminary design of the Savonius turbine Source: Tribology and transport group Faculty of Engineering BUAP; Solidworks 2018. (2020).

Using as a reference the design drawings of the Savonius vertical axis turbine previously made, both the faces and the tank cylinder were modified and the parts were relocated, obtaining as a final result a fully functional Savonius turbine as shown in Figure 4.

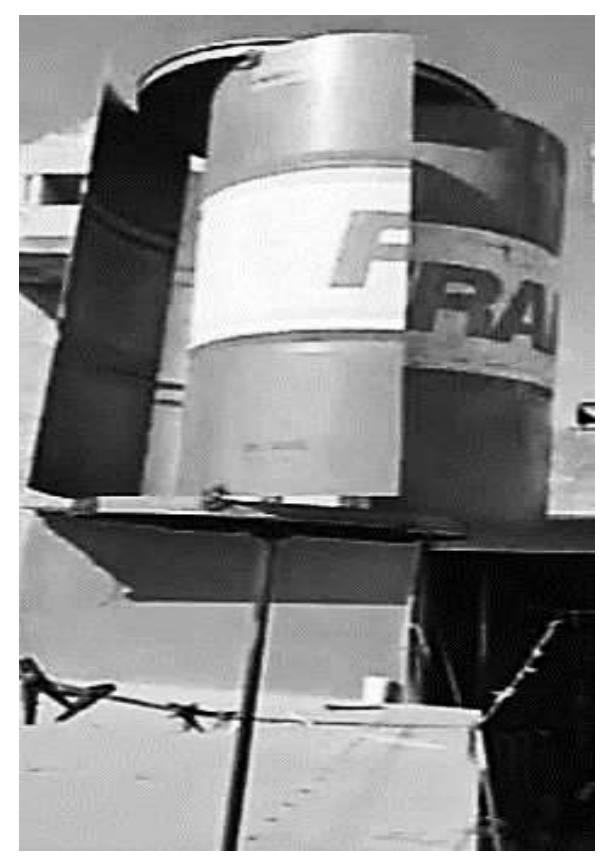

Figure 4 Savonius vertical shaft turbine

Source: Tribology and transport group. Faculty of Engineering. BUAP. (2020)

\section{Operating conditions}

Through the data collected in the psychrometric chart, as shows in table 1 it was calculated that the winds in the city of Puebla have an average linear speed of $8.03 \mathrm{~m} / \mathrm{s}$, the other operating conditions are dictated by the geometry of the turbine parts and their arrangement in the assembly. Benemérita Universidad Autónoma de Puebla [BUAP]. (2020). 


\begin{tabular}{|l|r|}
\hline Boundary Conditions & \multicolumn{2}{|c|}{ Value } \\
\hline Dry bulb temperature & $21{ }^{\circ} \mathrm{c}$ \\
\hline Wet bulb temperature & $14^{\circ} \mathrm{c}$ \\
\hline Absolute humidity & $0.0014 \mathrm{Kg} \mathrm{H} 2 \mathrm{O} / \mathrm{Kg}$ Air \\
\hline Relative humidity & $65 \%$ \\
\hline Enthalpy & $47.5 \mathrm{Kcal} / \mathrm{Kg}$ \\
\hline Dew temperature & $10.6{ }^{\circ} \mathrm{c}$ \\
\hline
\end{tabular}

Table 1 Parameters from psychrometric chart Source: Arellano F. (2003). Ahorro de energía del sistema de aire acondicionado del edificio administrativo del IMP, México, D.F. Instituto Politécnico Nacional p.p. 43

\subsection{TSR rate identification}

The Tip Speed Ratio (TSR) was calculated using equation 1, which relates the linear speed of the turbine to the linear speed perpendicular to the wind flow.

$\lambda=\frac{v}{V}=\frac{w r}{V}$

Where:

\section{$\lambda$ : Tip Speed Ratio}

$\mathrm{V}$ : Linear wind speed $(\mathrm{m} / \mathrm{s})$

$\mathrm{v}$ : Turbine linear speed $(\mathrm{m} / \mathrm{s})$

w: Turbine angular velocity ( $\mathrm{rad} / \mathrm{s})$

r: Turbine radius $(\mathrm{m})$

Where the linear velocity of the wind rotor will be described by equation 2 .

$v=w r=2 \pi f r$

Where:

\section{f: Frecuencia $(\mathrm{Hz})$}

Substituting the data in equation 1.

$\lambda=\frac{2 \pi(60 \mathrm{~Hz})(0.4425 \mathrm{~m})}{8.03 \mathrm{~m} / \mathrm{s}}$

Therefore.

$\lambda=20.7744$

However, given the design and adaptation of the vertical axis Savonius turbine built, and that it has five blades equidistant to its axis and have the same contact area, the TSR coefficient is divided by five, as shown in equation 3 .

$\lambda_{R}=\frac{\lambda}{5}$
Where:

$\lambda_{\mathrm{R}}$ : Actual Tip Speed Ratio

Sustituyendo los datos en la ecuación 3.

$\lambda_{R}=\frac{20.7744}{5}=4.1548$

\subsection{Drag coefficient}

The TSR helps us to measure the behavior of a body that rotates on its axis and is governed by aerodynamic drag, given the shape of the blades to capture the wind are perpendicular to the wind flows and has a large contact area; a unit drag coefficient will be estimated.

\subsection{Force and power of the wind flow captured by the turbine}

Based on the geometric characteristics of the wind rotor, the psychrometric chart of the State of Puebla (2135 meters above sea level) and the delimitation of the wind constant at $8.03 \mathrm{~m} / \mathrm{s}$, the equations of the force captured by the turbine, and the projected power with the rotor assembled directly to the shaft were developed.

Contact area $=\mathrm{A}=0.31911 \mathrm{~m}^{2}$

Dragging constant $=\mathrm{CA}_{\mathrm{A}}=1$

Wind speed $=\mathrm{v}=8.03 \mathrm{~m} / \mathrm{s}$

Air density $=\rho=1.225 \mathrm{~kg} / \mathrm{m}^{3}$

Turbine radius $=\mathrm{r}=0.4425 \mathrm{~m}$

The force exerted by the air flows acting on the turbine blades is defined by equation 4 .

$F_{w}=C_{A} \frac{1}{2} \rho A v^{2}$

Substituting the data in equation 4.

$=\left(\frac{1}{2}\right)\left(1.225 \mathrm{~kg} / \mathrm{m}^{3}\right)\left(0.31911 \mathrm{~m}^{2}\right)(8.03 \mathrm{~m} / \mathrm{s})^{2}$

Therefore.

$F_{w}=12.6031 \mathrm{~N}$

The power per part of the wind speed is described in equation 5 .

$P_{w}=C_{A} \frac{1}{2} \rho A v^{3}$

Substituting the data in equation 5. 
$=\left(\frac{1}{2}\right)\left(1.225 \mathrm{~kg} / \mathrm{m}^{3}\right)\left(0.31911 \mathrm{~m}^{2}\right)(8.03 \mathrm{~m} / \mathrm{s})^{3}$

Therefore.

$P_{w}=101.2029 \mathrm{~W}$

\section{CFD analysis of the Savonius wind turbine}

To observe the behavior of the wind flows as they rotated the wind turbine, the CAD model was imported into the ANSIS 2020 R2 CFD program. As shown in Figure 5, a control volume was implemented to define the domain through which the wind flow would pass through the wind rotor. Likewise, a rotation domain was also declared to allow the model to rotate.

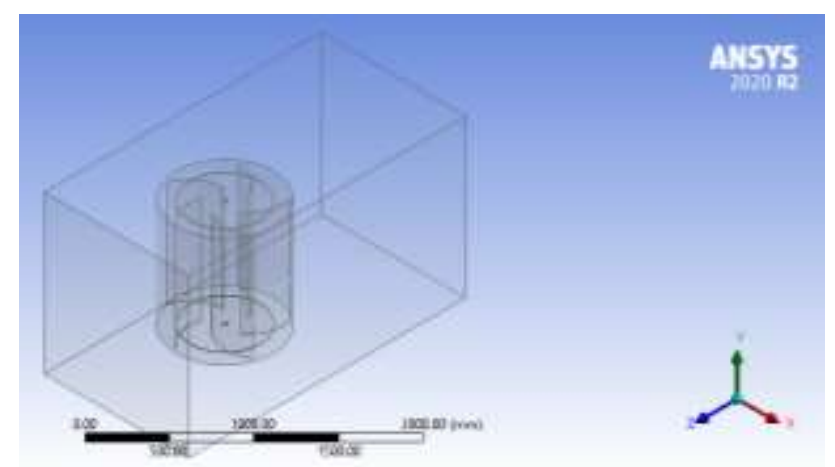

Figure 5 Implementation of control and rotation domains Source: Grupo de tribología y transporte. Facultad de ingeniería. BUAP; ANSYS R2 2020. Licencia estudiantil. (2021)

The K-Epsilon viscosity model achievable with a near-wall treatment scalable to the wall was declared. In addition to programming the boundary parameters given in Table 1.

\begin{tabular}{|l|l|}
\hline \multicolumn{1}{|c|}{ Parameters } & $\begin{array}{l}\text { Coefficients and Features } \\
\text { Density }=1.225 \mathrm{~kg} / \mathrm{m}^{3} \\
\text { Viscosity }=1.784 \mathrm{e}-05 \\
\mathrm{~kg} / \mathrm{m} \cdot \mathrm{s}\end{array}$ \\
\hline Inlet & $8.03 \mathrm{~m} / \mathrm{s}$ hacia to $-\mathrm{Z}$ \\
\hline $\begin{array}{l}\text { Relative pressure in } \\
\text { control volume openings } \\
\text { (except Inlet) }\end{array}$ & $1.00863 \mathrm{~atm}$ \\
\hline $\begin{array}{l}\text { Direction of rotation } \\
\text { of the rotation domain }\end{array}$ & $\mathrm{Y}=1$ \\
\hline $\begin{array}{l}\text { Maximum speed } \\
\text { of rotation of the rotation } \\
\text { domain }\end{array}$ & $18.1468 \mathrm{rad} / \mathrm{s}$ \\
\hline Prandt TDR number & 1.2 \\
\hline Prandt TKE number & 1 \\
\hline
\end{tabular}

Tabla 2 CFD analysis boundary parameters

Source: Grupo de tribología y transporte. Facultad de Ingeniería. BUAP. (2021).
From these data, the simulation was run in the CFX tool of ANSYS R2 2020, obtaining the results of pressure, angular and linear velocity of the air currents in the turbine, shown in Figures 6, 7, and 8 respectively.

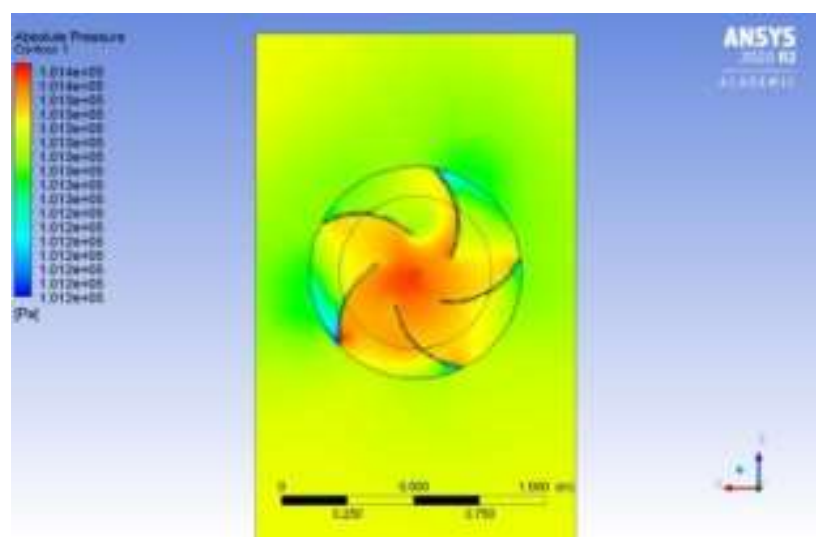

Figura 6 Absolute pressure CFD results of the Savonius vertical axis turbine

Sourse: Grupo de tribología y transporte. Facultad de Ingeniería. BUAP; ANSYS R2 2020. CFX. Licencia estudiantil. (2021)

Figure 6 shows how the absolute pressure is concentrated in the center of the rotor and is distributed uniformly across the blades, focusing on the contact areas of the turbine, allowing a constant rotation in the desired direction.

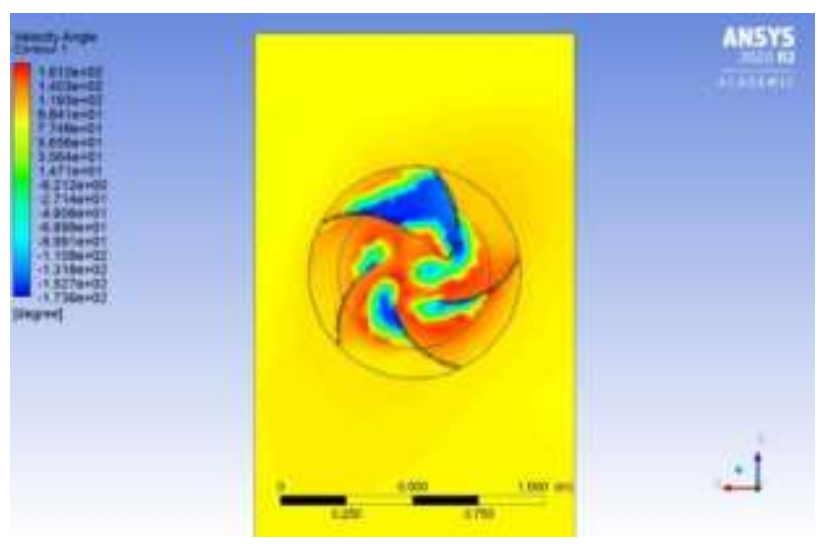

Figura 7 Angular velocity CFD results of the Savonius vertical axis turbine

Sourse: Grupo de tribología y transporte. Facultad de ingeniería. BUAP; ANSYS R2 2020. CFX. Licencia estudiantil. (2021)

Since the analysis starts from the steadystate of the turbine, it can be seen in Figure 7 how the angular velocity of the air reaches its maximum point near the blade transverse to the wind direction and since the inertia of the prototype has not yet been broken; this velocity dissipates as the turbine rotates. However; after a few seconds the angular velocity of the flow near the turbine will be almost symmetrical, still centering on the wing transverse to the wind. 


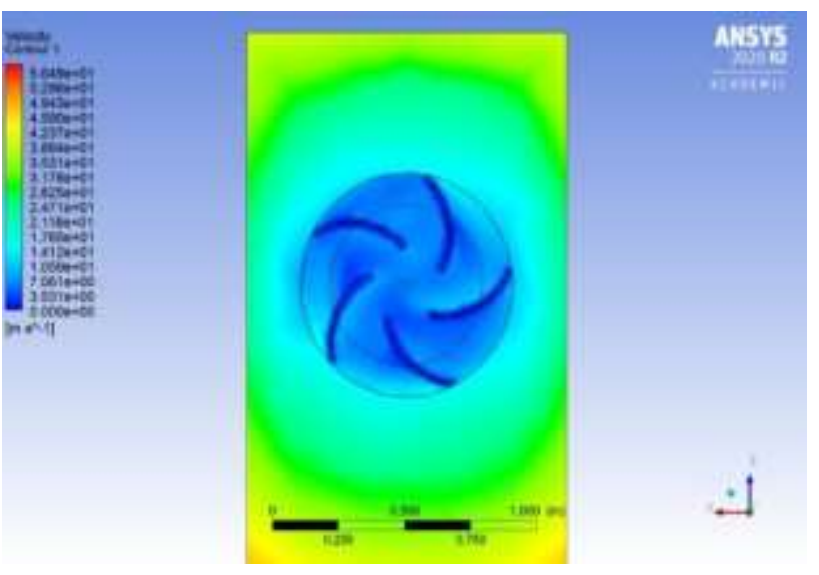

Figura 8 CFD linear velocity results of the Savonius vertical axis turbine

Source: Grupo de tribología y transporte. Facultad de Ingeniería. BUAP. ANSYS R2 2020. Licencia estudiantil. (2021)

In general, a linear flow velocity analysis on a vertical axis turbine tends to be unimportant because the wind speed vectors do not usually alter linearly, even after breaking the inertia of the prototype. Anyway, it will be considered because it is one of the main parameters contributing to turbine performance and blade degradation.

Figure 8 shows how the prototype, in steady-state, impedes the wind flow and gradually reduces its speed (it can be observed how the speed decreases in the control volume; comparing the before and after contacting the turbine). However, being analogous to the angular velocity analysis in Figure 7, the linear velocity of the flow begins to excite the rotor from the contact of the fluid with the transverse blade to the wind, behaving uniformly over almost the entire area of the blade.

\section{Results}

Table 3 contains the data obtained from the Savonius turbine geometry and the corresponding psychrometric data.

\begin{tabular}{|l|r|}
\hline \multicolumn{1}{|c|}{ Description } & \multicolumn{1}{|c|}{$\begin{array}{c}\text { Calculated } \\
\text { value }\end{array}$} \\
\hline Top speed rate & 4.1548 \\
\hline Intercepted flow force & $12.6031 \mathrm{~N}$ \\
\hline $\begin{array}{l}\text { Projected power } \\
\text { (With shaft assembled directly to } \\
\text { the rotor) }\end{array}$ & $101.2029 \mathrm{~W}$ \\
\hline
\end{tabular}

Table 3 Calculated results

Source: Tribology and Transport Group. Faculty of Engineering. BUAP. (2021)
As far as the CFD analysis is concerned, it can be interpreted that the wind flow intercepted by the turbine blades starts to form air eddies that excite the rotor motion and these dissipate up to $135^{\circ}$ with respect to the $\mathrm{XZ}$ axis after capture.

\section{Results discussion}

In the area of sustainability, the wind turbine design proposed in this research will benefit society by providing an alternative in the capacity to generate electricity in an environmentally friendly and economically viable way, in the same way, anyone who has access to a tank has the possibility of making a similar assembly. On the sustainable side, the Savonius model in the urban environment adapts perfectly to environmental conditions and does not have to be directed in the direction of air currents. Therefore, these wind rotor designs are the most suitable for closed cities, fostering a culture of awareness that cares for the environment and the integration of innovative clean energy generation systems in urban environments.

\section{Annexes}

Arellano F. (2003). Ahorro de energía del sistema de aire acondicionado del edificio administrativo del IMP, México, D.F. Instituto Politécnico Nacional p.p. 4

\section{Conclussions}

In this study, the adaptation of a Savonius vertical axis turbine from a $200 \mathrm{~L}$ tank has been proposed for implementation in large cities. However, the results obtained in this analysis demonstrate the limited generation potential and the great challenge of generating large amounts of kilowatts sustainably, not to mention the large intermittencies that are typical of wind technologies. Even so, the Savonius rotor represents a great advantage in sustainably producing energy in urban environments, as it does not need to be directed into the airflow, and by having an outstanding performance in handling turbulence as many vertical axis turbine designs such as the Darrieus. 


\section{References}

(2018). Programa de Desarrollo del Sistema Eléctrico Nacional 2018-2032. Recuperado de: https://www.gob.mx/sener/acciones-yprogramas/programa-de-desarrollo-del-sistemaelectrico-nacional-33462

(2021). Estadística de la Energía Generada Liquidada Agregada (MWh) Intermitente y Firme por Tipo de Tecnología. Sistema Eléctrico Nacional. Días de Operación del Mes de: febrero 2021. Proceso de Liquidación: Original (L0). https://www.cenace.gob.mx/SIM/VISTA/REP ORTES/EnergiaGenLiqAgregada.aspx

(2021). Red Automática de Monitoreo Meteorológico 12: DIAU-BUAP. Benemérita Universidad Autónoma de Puebla. http://urban.diau.buap.mx/estaciones/ramm/ram m.html

ANSYS. (2021). https://www.ansys.com/

Batista, H. (2000). Las turbinas eólicas. Universidad Nacional de la Plata.

Barrera, J., Jurado, F., Razo, J., González, R. Aerogenerador de eje vertical para aplicaciones In-situ. Análisis y modelado de un aerogenerador de eje vertical. Innovación y sustentabilidad Tecnológica. Instituto Tecnológico de Misantla.

Canalejo, D. (2011). Generador eólico para uso doméstico. Escuela Universitaria Politécnica de Mataró. 5-7.

Diago, C. (2019). Diseño de un aerogenerador Savonius para uso doméstico. Universidad Tecnológica de Valencia. 41-45.

Estrella, B. (2008). Prototipo Experimental Turbina Eólica de Eje Vertical. Tecnológico de Monterrey. 8-19.

Guanoluisa, E. (2011). Aplicación del método de elementos finitos en la dinámica de fluidos. 3850.

Huacuz, J. (2016). Tendencias en el Desarrollo de la Tecnología Eólica. Premio Nacional de Tecnología e Innovación.
López, A. (2013). Métodos numéricos aplicados a la mecánica de fluidos. Universidad de Zaragoza. 19-29.

Regueiro, R. (2011). Las implicaciones ambientales del proceso de implantación de parques eólicos: La situación en Galicia. Revista Galega de Economía. Volumen 20.3-8.

Saavedra, A., Alejos, R. (2019). Diseño de la geometría de un aerogenerador de eje vertical tipo Savonius. 2-3.

Solidworks.

(2021)

https://www.solidworks.com/es

Torres, A. (2015). Simulación y análisis de interacción fluido-estructura en alabe de turbina de motor a reacción mediante método por elemento finito. Instituto Politécnico Nacional.

Tseng, Y., Kuo, C. (2011). Engineering and construction torsional responses of glassfiber/Epoxy composite blade shaft for a small wind turbine. Procedia Engineering 14.

Vázquez, M. (2007). Diseño de una turbina eólica de eje vertical con rotor mixto.

Villanueva, J., Álvarez, R. (2007). Modelado del coeficiente de potencia de un aerogenerador por efecto de fricción. Universidad Nacional Autónoma de México. 